\title{
A design for Six Sigma case Study: Creating an IT change management system for a mid-size accounting firm
}

\author{
Patricia Long ${ }^{1}$, Jamison Kovach ${ }^{1}$, David Ding ${ }^{1}$ \\ ${ }^{1}$ Department of Information and Logistics Technology, University of Houston, Houston, TX USA \\ *Corresponding Author: e-mail: jkovach@uh.edu, Tel 713-743-1704, Fax.713-743-4032
}

\begin{abstract}
Accounting firms provide financial services, such as bookkeeping, tax returns, and audit services. Unfortunately, employees sometimes encounter problems with Information Technology (IT) systems that interrupt their work. While the IT department is responsible for fixing these problems, their ability to do so is often hindered by the lack of a formal IT change management system. Such a system would improve the timely identification of prior changes to IT systems that may be related to current problems faced by the IT department, thereby reducing unplanned downtime and IT staff frustration. This work describes a case study that used the Design for Six Sigma methodology to establish a process for effectively managing IT system changes for a mid-size accounting firm. This structured design approach provided an underlying framework for this organization to translate users' needs/expectations into the design of a new system that helped to improve the communication and awareness of system changes within the IT department.
\end{abstract}

Keywords: Design for Six Sigma, service processes, IT systems, change management, accounting firms, employee buy-in

DOI: http://dx.doi.org/10.4314/ijest.v3i7.5S

\section{Introduction}

The Six Sigma methodology is a well-known, structured approach to problem solving that focuses on improving existing processes by reducing variation (Chowdhury, 2003). This approach represents one of the most recent evolutions of the quality movement and has been formally defined as "....an organized, parallel-meso structure to reduce variation in organizational processes by using improvement specialists, a structured method, and performance metrics with the aim of achieving strategic objectives" (Schroeder et al., 2008). Here, parallel-meso refers to the fact that Six Sigma operates in parallel with an organization's "normal" ways of doing things that connects multiple levels of an organization (i.e., meso as taken from meso theory, which concerns the integration of micro- and macro-levels of analysis).

In some form, thousands of companies have implemented Six Sigma, and several major organizations, including General Electric, Caterpillar, and Bank of America, have reported significant financial savings as a result of Six Sigma projects (Montgomery \& Woodall, 2008). Yet, because Six Sigma does not target fundamental changes to the structure of the underlying production/service process, organizations typically hit a point beyond which improvements are difficult, if not impossible, to achieve (Yang, 2005). Research has suggested that this phenomenon occurs when organizations reach a five-sigma quality level (i.e., 233 defects/errors per million opportunities), and that it is the quality of the original product/service design that inhibits further process improvement (Harry \& Schroeder, 2000; Banuelas \& Antony, 2003a, 2003b). In addition, Six Sigma is often viewed as a reactive approach that does not address new product/service development, which is thought to be a more proactive approach that builds quality into products/services (Yang \& El-Haik, 2003; Shahin, 2008).

To address this issue, Six Sigma applications have grown to include the design and redesign of both products and services, which is known as Design for Six Sigma (DFSS) (El-Haik \& Roy, 2005). DFSS is a relatively new concept that provides a structured method for design activities aimed at achieving Six Sigma performance (Schroeder et al., 2008; Hasenkamp, 2010). This approach was developed through a joint effort between the Department of Defense and NASA (Brue \& Launsby, 2003). Recently, DFSS has 
been used successfully at Delphi Electronics (Treichler et al., 2002), General Electric, Seagate, and Toshiba (Berardinelli et al., 2009), just to name a few. By designing quality into products or services, customers' needs and expectations are fulfilled beginning the first day the product/service is offered (El-Haik \& Roy, 2005; Brue \& Launsby, 2003). The goal of a DFSS project is to translate customer expectations into design requirements, select and implement the best design alternative, and verify that the new product/service meets the needs of the environment for which it was designed (Shahin, 2008; Chowdhury, 2002).

It has been suggested that support from the engineering design group within an organization is required to make DFSS projects successful (Kulahci, 2010). While this type of support many be critical in some environments, it is not necessarily true for every DFSS project. In fact, statements like this seem to suggest that only those involved in design functions (i.e., new product/service development) need to use an approach such as DFSS. It is quite common, however, that in the course of typical problem solving activies, situations arise in which new products, services, or processes need to be developed. That is, when the problem under investigation does not involve an existing process (i.e., one does not yet exist) or the existing process is operating so poorly that it is necessary to abandon it altogether and start over, more widely-known process improvement methodologies, like Six Sigma, are not appropriate. Instead, to address these type of problems, improvement teams need additional strategies that focus on designing/redesigning products and services like DFSS (Montgomery \& Woodall, 2008). The DFSS approach can help improvement teams design new products or services that address customers' needs or redesign existing processes, either to establish a process for those that are complely broken/largely informal or to create a better design for those that have already been improved to the point that additional efforts to make improvements have not been successful.

The purpose of this paper is to describe a case study conducted within a small Information Technology (IT) department at a midsize accounting firm. This case specifically demonstrates how the five phase DFSS methodology, known as DMADV (Define, Measure, Analyze, Design, and Verify), was used as an underlying framework to establish an IT change management process for this department. Change management is the process responsible for controlling and managing requests to change aspects of the IT infrastructure or service and includes activities such as software upgrades, server migrations, data moves and deletions, alterations to file permissions, and the creation and modifications of user accounts. When this project began, the department's approach to managing IT system changes was very informal and ineffective. IT staff simply communicated changes to one another verbally or through email. As a result, changes were often not communicated well and/or were not acknowledged by others. Hence, the lack of a formally defined IT change management system meant there was no way to determine what system changes had been made that may be responsible for future problems faced by the IT department. The next section describes the company and department in which this case study was conducted as well as the motivation for undertaking the DFSS project. The work completed in each phase of the project is then explained in detail.

\section{Company Background}

Gainer, Donnelly \& Desroches is a mid-size certified public accounting firm with approximately 140 employees that specializes in serving individuals and private entrepreneurs. In 2009, this firm was listed as the eighth largest public accounting firm in the greater Houston metropolitan area (Ferweda, 2009). Gainer, Donnelly \& Desroches currently employs more than 60 certified professional accountants in Texas and has been in business for more than 60 years. This firm offers professional services, including audit, tax, bookkeeping and risk services, in a variety of industries, such as real estate, energy, and manufacturing. It also provides services to assist high net worth individuals and non-profit organizations.

Like most organizations, the IT department within Gainer, Donnelly \& Desroches supports the firm by ensuring that critical software applications and necessary equipment are available and functioning properly so that employees can complete their work tasks. Unfortunately, employees sometimes encounter problems with IT systems that hinder the daily productivity of the organization. When the necessary IT systems are not available, it interrupts the flow of work for employees, thereby potentially causing a loss of revenue. It is the responsibility of the IT department to maintain these systems and fix these problems. At Gainer, Donnelly \& Desroches, this department is small and consists of only four employees - two IT staff, one external consultant, and the IT manager, who reports directly to the Managing Partner of the firm. At the time of this case study, the IT department identified unplanned IT system downtime as one of their major opportunities for improvement. They felt strongly that their ability to address problems that cause downtime was hindered by the lack of a formal IT change management system within their department.

Change management is generally considered a central IT control that is responsible for managing requests to change aspects of the IT infrastructure to improve organizational operations while minimizing the risk of disrupting IT services (Stickel, 2005). Within most organizations, many IT changes occur on a daily basis including daily activities (i.e., installing, moving, adding and and/or changing hardware/software), new projects, enhancement projects, and maintenance activities. The number of change requests typically ranges from 300/month for a small company to 10,000/month for a large Fortune 500 company (Brittain, 2007). While the number of change requests within Gainer, Donnelly \& Desroches falls on the lower end of this range because it is only a mid-size firm, the problems that result from poor IT change management are significant to the organization. In addition to unplanned downtime, these problems included security risks, compliance issues, and frustration for the IT department staff. The following discussion provides justification for the importance of these problems within Gainer, Donnelly \& Desroches and beyond. 
Research suggests that $80 \%$ of unplanned downtime can be attributed to an IT system change (Brittain, 2007). Half of the time, this problem is the result of application failures, and the other half is caused by operator errors. Because companies are increasingly reliant on IT services, the potential for IT system failures represent an increased risk for many organizations (Microsoft, 2010). In fact, $40 \%$ of companies that suffer a critical IT system failure go out of business within one year of the event (Pheonix, 2010). Furthermore, the Verizon Business 2009 Data Breach Investigations Report identified errors as a contributing factor in nearly all data breaches. According to the report, "Poor decisions, misconfigurations, omissions, noncompliance, process breakdowns and the like undoubtedly occur somewhere in the chain of events leading to the data breach" (Verizon-Business, 2009). To address these issues, private companies like Gainer, Donnelly \& Desroches often use "best practices" from the corporate compliance field to help protect owners' capital and shareholders' equity and to increase client confidence by having strong control functions, which signify the importance of quality, accountability, and accuracy within the organization (Marwil \& Burgdoerfer, 2006).

Effectively managing IT system changes is challenging, as evidenced by change management being listed in the top 10 IT issues of 2008 (Allison \& DeBlois, 2008). A recent poll suggests that IT organizations continue to struggle with the development of a change control policy that is consistently followed by the entire IT department (Brittain, 2009). Another study revealed that $60 \%$ of IT managers believe that their change control processes are not effective in communicating and coordinating changes in their production environments (Stickel, 2005). The IT manager at Gainer, Donnelly \& Desroches agreed with these findings. After a decade of working in the IT field, she had yet to observe or determine an effective method of managing IT systems changes. In addition, as recently as 2007 almost 50\% of companies surveyed considered themselves at the "reactive" maturity level in the IT change management process (Brittain, 2008). At this level, organizations like that of Gainer, Donnelly \& Desroches' IT department often cope with high risk changes, continue to answer repetitive user requests, and react to the same problems over and over again. It is interesting to note, however, that research has shown the attribute of the work environment most valued by service employees is being able to achieve results for their customers. Thus, having the necessary knowledge and tools available to do their jobs result in more productive staff and more satisfied customers (Heskett et al., 2008). Unfortunately, this was not currently the case for the IT department at Gainer, Donnelly \& Desroches.

To address many of these issues, this department initiated a DFSS project where the goal was to develop an effective IT change management system. They felt this new system would help to reduce unplanned downtime and IT staff frustration, as well as improve IT system security and compliance issues. They also believed this project had the potential to positively impact productivity, customer satisfaction, and bottom-line performance for the organization as a whole. The specific details regarding the execution of this project are discussed in the following section.

\section{Implementation of DFSS}

The DFSS project undertaken at Gainer, Donnelly \& Desroches was led by the IT department manager and took approximately nine months to complete. All four members of the IT department were heavily involved in this project as members of the design team. Additional input for the project was solicited from other employees, including the Managing Partner, as well as other project stakeholders and several external resources. As discussed previously, this project used the DMADV approach to create an effective method for managing IT system changes. In this section, an overview of the DMADV process is provided, which is then followed by a description of the step-by-step approach used in the DFSS project conducted within the IT department at Gainer, Donnelly \& Desroches.

In the Define phase of a DFSS project, the goals of the project are identified and a business case is developed. In this stage, project management techniques are typically used to create a project charter and develop a project plan that is aligned with the objectives of the overall organization (Gitlow, Levine, \& Popovich, 2006). During the Measure phase, the customer is identified and their needs are quantified. The customer's expectations are obtained using research methods such as interviews and/or surveys. Using this information, the Critical to Quality (CTQ) features of the service process are selected and ways to measure how well the design fulfills the customers' needs are established (Brue \& Launsby, 2003). In the Analyze phase, techniques that foster creativity are used to develop several high-level, potential design ideas (El-Haik \& Roy, 2005). Prioritization tools are then used to choose among alternative design ideas and these designs are evaluated to determine the best overall design through focus groups and/or simulations. During the Design phase, a detailed design of the new service process is developed. In this stage, the Critical to Process (CTP) elements of the selected design are identified and the capability of the design to meet the established targets is assessed (Brue \& Launsby, 2003). Finally, the team pilot tests the design of the new service process in the Verify phase. During this test, the new service is validated to ensure that it meets customers' requirements. As a result of the pilot test, if necessary, final adjustments are made to the design (El-Haik \& Roy, 2005). A discussion regarding how this process was used to develop an IT change management system for Gainer, Donnelly \& Desroches is provided in the following sections.

3.1 Define: The first step in the DFSS project undertaken within the IT department at Gainer, Donnelly \& Desroches was to use project management techniques to create a project charter and develop a project plan that was aligned with the objectives of the organization. The charter for this project identified the roles and responsibilities for each member of the design team as well as the 
objective of the project. As described in the following problem and mission statements, the overall goal of this project was to create a method for effectively managing IT system changes within the IT department at Gainer, Donnelly \& Desroches.

Problem Statement: The IT department at Gainer, Donnelly \& Desroches does not have a formal process for managing IT system changes, which results in unplanned downtime, security risks, compliance issues, and frustration for the IT staff - all of which negatively impact organizational productivity.

Mission Statement: Design a process for effectively managing IT system changes, which will result in increased productivity and improved customer satisfaction.

Also as part of the define phase, a project plan was developed. This plan, the execution of which is described in the following sections, included the following steps:

1. Map the current process using a SIPOC diagram and a service blueprint.

2. Conduct interviews with all IT staff, etc. to determine the needs for the new process.

3. Organize the needs obtained from interviews using an affinity diagram.

4. Prioritize the needs for the new process through a needs assessment survey.

5. Benchmark other organizations to determine initial design ideas.

6. Conduct brainstorming sessions with all IT staff, etc. to determine additional design ideas.

7. Organize preliminary design ideas using an affinity diagram.

8. Determine the requirements for the new process using a needs-metrics matrix.

9. Establish baseline measurements for process requirements through a user survey.

10. Select the best design idea using a concept selection matrix.

11. Pilot test the design of the new process.

12. Determine how well the new process fulfills the needs for which it was designed.

To map the operations within the IT department at a high level, the SIPOC diagram shown in Figure 1 was created. This diagram shows that the work completed by the IT department, which mainly involves maintaining systems and fixing problems, directly affects company employees, IT staff, and consultants and indirectly affects the firm's clients. In essence, the IT department provides an internal service within the company to support the firm's overall operations.

\begin{tabular}{|c|c|c|c|c|}
\hline Suppliers & Inputs & Process Steps & Outputs & Customers \\
\hline $\begin{array}{l}\text { Help Desk Staff } \\
\text { IT Manager } \\
\text { Training } \\
\text { Department } \\
\text { External } \\
\text { Consultants } \\
\text { Vendors } \\
\text { HR Department } \\
\text { Users } \\
\text { Staff }\end{array}$ & $\begin{array}{l}\text { User Issues } \\
\text { Staff Experience } \\
\text { Staff Training } \\
\text { Staff Availability } \\
\text { FAQ Database } \\
\text { User Availability } \\
\text { Hardware/ } \\
\text { Software } \\
\text { New/Terminated } \\
\text { Users }\end{array}$ & $\begin{array}{l}\text { 1. Receive Requests via } \\
\text { Email/Phone } \\
\text { 2. Gather Customer } \\
\text { Information } \\
\text { 3. Classify Issue } \\
\text { 4. Analyze Issue } \\
\text { 5. Solve Problem } \\
\text { 6. Manage Requested Changes } \\
\text { 7. Install New Hardware/ } \\
\text { Software } \\
\text { 8. Perform System } \\
\text { Maintenance }\end{array}$ & $\begin{array}{l}\text { Problem Resolved } \\
\text { Standard } \\
\text { Operating } \\
\text { Procedure } \\
\text { Ticket Closed \& } \\
\text { Logged } \\
\text { Documentation } \\
\text { Resolution Added } \\
\text { to FAQ Database } \\
\text { New } \\
\text { Configurations/ } \\
\text { Versions } \\
\text { New Hardware/ } \\
\text { Software Installed }\end{array}$ & $\begin{array}{l}\text { Company } \\
\text { Employees } \\
\text { Company Clients } \\
\text { IT Staff } \\
\text { External } \\
\text { Consultants }\end{array}$ \\
\hline
\end{tabular}

Figure 1. IT department operations at Gainer Donnelly \& Desroches

To explore the work processes within the IT department in further detail, a service blueprint was created for online change requests, as shown in Figure 2. A service blueprint is a process-oriented design technique intended specifically for documenting and improving service processes that is often used in quality improvement projects. This special type of process map provides a 
visual representation of the service process that looks somewhat like a swim-lane diagram and denotes the line of 1) interaction (i.e., where the service provider interacts with the customer), 2) visibility (i.e., where the visibility of the service process by the customer ends), and 3) internal interaction (i.e., where the behind the scenes operations within the service process occur). This approach to process mapping specifically differentiates between "onstage" (i.e., aspects of the service process that are visible to the customer) and "backstage" (i.e., aspects of the service process that are not visible to the customer) activities performed by the service provider, which highlights the customer's role in the process (Bitner, Ostrom, \& Morgan, 2008). In this case, the onstage activities performed by the IT department include all communications with the users, and the backstage activities include researching solutions to problems, evaluating requested changes, and testing and installing new hardware and software. In addition, the service blueprint shows each point in the process where the employees interact with the customer/user (Bitner, 2008). Here, the IT staff interacts with users when they work to resolve IT issues, which includes developing/pilot testing solutions and training users on new solutions. Mapping these operations helped to organize the collective thinking of the design team so that each member had a detailed understanding of the work processes involved in this project.

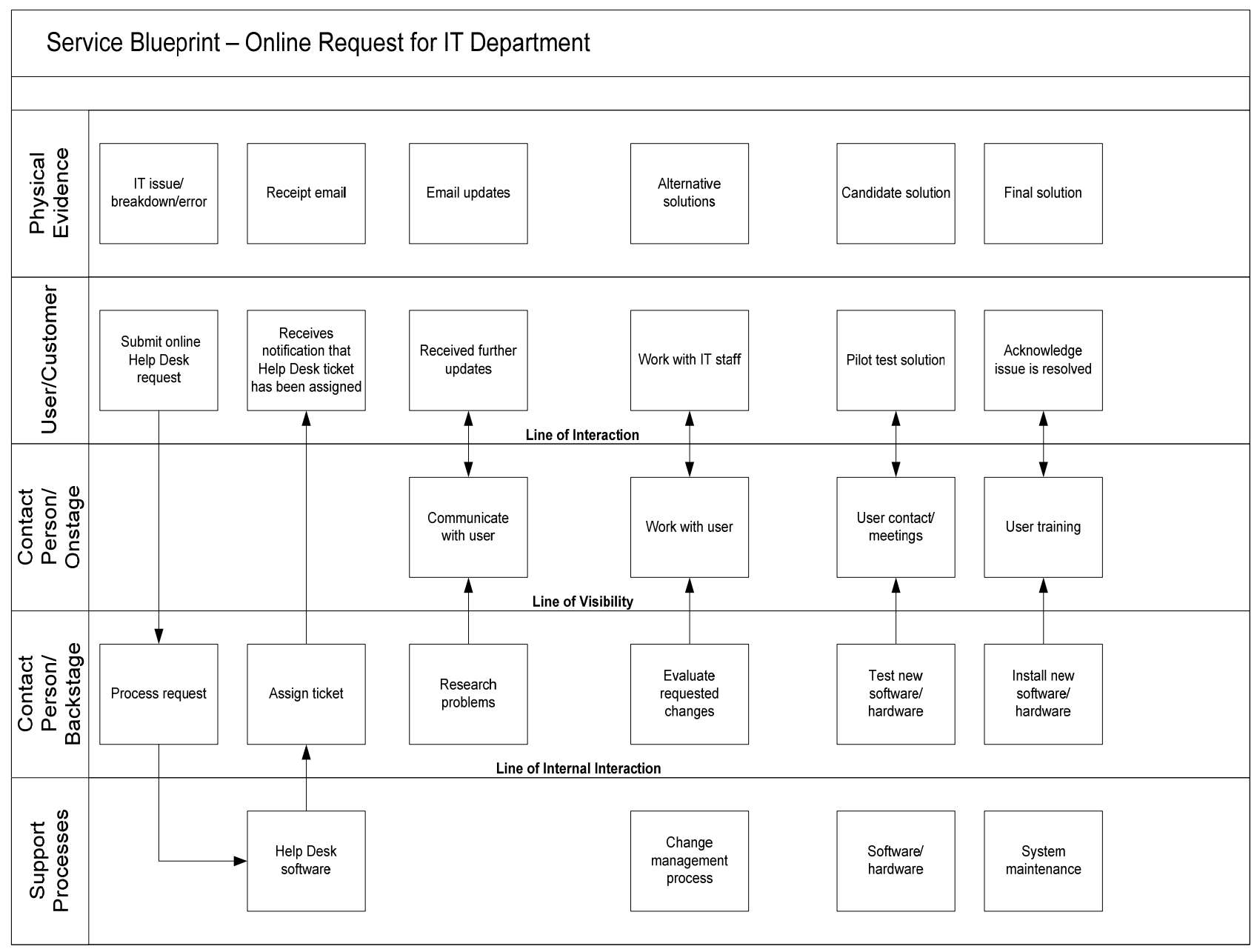

Figure 2. Flow of work for IT help requests submitted online

3.2 Measure: In the measure phase, a user needs analysis was conducted using the approach described by Ulrich and Eppinger (2004). The user's (i.e., employee's) expectations for an IT change management system were obtained through interviews with IT staff, consultants, and other IT system users. As shown in Table 1, six employees participated in these interviews in which they were asked to describe their typical uses, likes, dislikes, and suggested improvements regarding the current system. The responses obtained from these interviews were then translated into "needs" that an IT change management system should fulfill, as depicted by the example interview shown in Table 2 . The needs elicited from these interviews were then organized into an affinity diagram, as illustrated in Figure 3, by a small group of IT staff who participated in the initial round of interviews. 
Table 1. Interview Participants

\begin{tabular}{|l|c|c|c|c|}
\hline \multirow{2}{*}{$\begin{array}{l}\text { IT System } \\
\text { Level of Use }\end{array}$} & \multicolumn{4}{|c|}{ Type of User } \\
\cline { 2 - 5 } & IT Staff & Consultant & Employee & Auditor \\
\hline Frequently & 3 & & & \\
\hline Occasionally & & 1 & & \\
\hline Rarely & & & 1 & 1 \\
\hline
\end{tabular}

Table 2. Interview data sheet example showing needs translation

\begin{tabular}{|c|c|c|c|}
\hline \multicolumn{3}{|l|}{ Interviewee: \#2 } & Type of User: IT Staff \\
\hline Question & \multicolumn{2}{|c|}{ Response } & Interpreted Need \\
\hline $\begin{array}{l}\text { 1. Typical uses, i.e., what do you } \\
\text { need an IT Change Management } \\
\text { System (CMS) for? }\end{array}$ & \multicolumn{2}{|r|}{$\begin{array}{l}\text { 1. Any impact to users and other } \\
\text { administrators }\end{array}$} & $\begin{array}{l}\text { The IT CMS can be used for all } \\
\text { changes that impact users or } \\
\text { other system administrators. }\end{array}$ \\
\hline \multirow[t]{2}{*}{$\begin{array}{l}\text { 2. Likes of the current IT CMS } \\
\text { (email/verbal) }\end{array}$} & \multicolumn{2}{|r|}{ 1. Easy to make changes } & $\begin{array}{l}\text { 1. The IT CMS makes it easy to } \\
\text { make changes. }\end{array}$ \\
\hline & \multicolumn{2}{|r|}{ 2. $\quad$ Changes can be made quickly } & $\begin{array}{l}\text { 1. The IT CMS helps to make } \\
\text { changes quickly. }\end{array}$ \\
\hline \multirow[t]{2}{*}{$\begin{array}{l}\text { 3. Dislikes of the current IT CMS } \\
\text { (email/verbal) }\end{array}$} & \multirow{2}{*}{\multicolumn{2}{|c|}{$\begin{array}{l}\text { 1. No control over changes that } \\
\text { other administrators make }\end{array}$}} & $\begin{array}{l}\text { 1. The IT CMS limits changes } \\
\text { made by other systems } \\
\text { administrators. }\end{array}$ \\
\hline & & & $\begin{array}{l}\text { 2. The IT CMS communicates } \\
\text { changes made by other system } \\
\text { administrators. }\end{array}$ \\
\hline 4. Suggested improvements & \multicolumn{2}{|c|}{ 1. None } & --- \\
\hline
\end{tabular}

To prioritize users' needs, the information summarized in the affinity diagram (Figure 3) was used to create a survey, which is displayed in Figure 4. In this survey, respondents were asked to rate the importance of the needs that the IT change management system should fulfill using a 5-point scale, where a rating of 1 represented "undesirable" and 5 represented "critical." pproximately 14 employees at Gainer, Donnelly \& Desroches participated in this survey, including the IT manager, all IT staff, their consultant, and several employees from outside the IT department. The results obtained from the survey, shown in Figure 5, were analyzed to determine the most important users' needs, thus identifying the characteristics/features that the new process for managing IT system changes should fulfill. Analysis of these data using a chi-square test indicated the importance ratings identified through the survey are different from expected values $\left(\chi^{2}=149.65, p\right.$-value $\left.=<0.0001\right)$. 


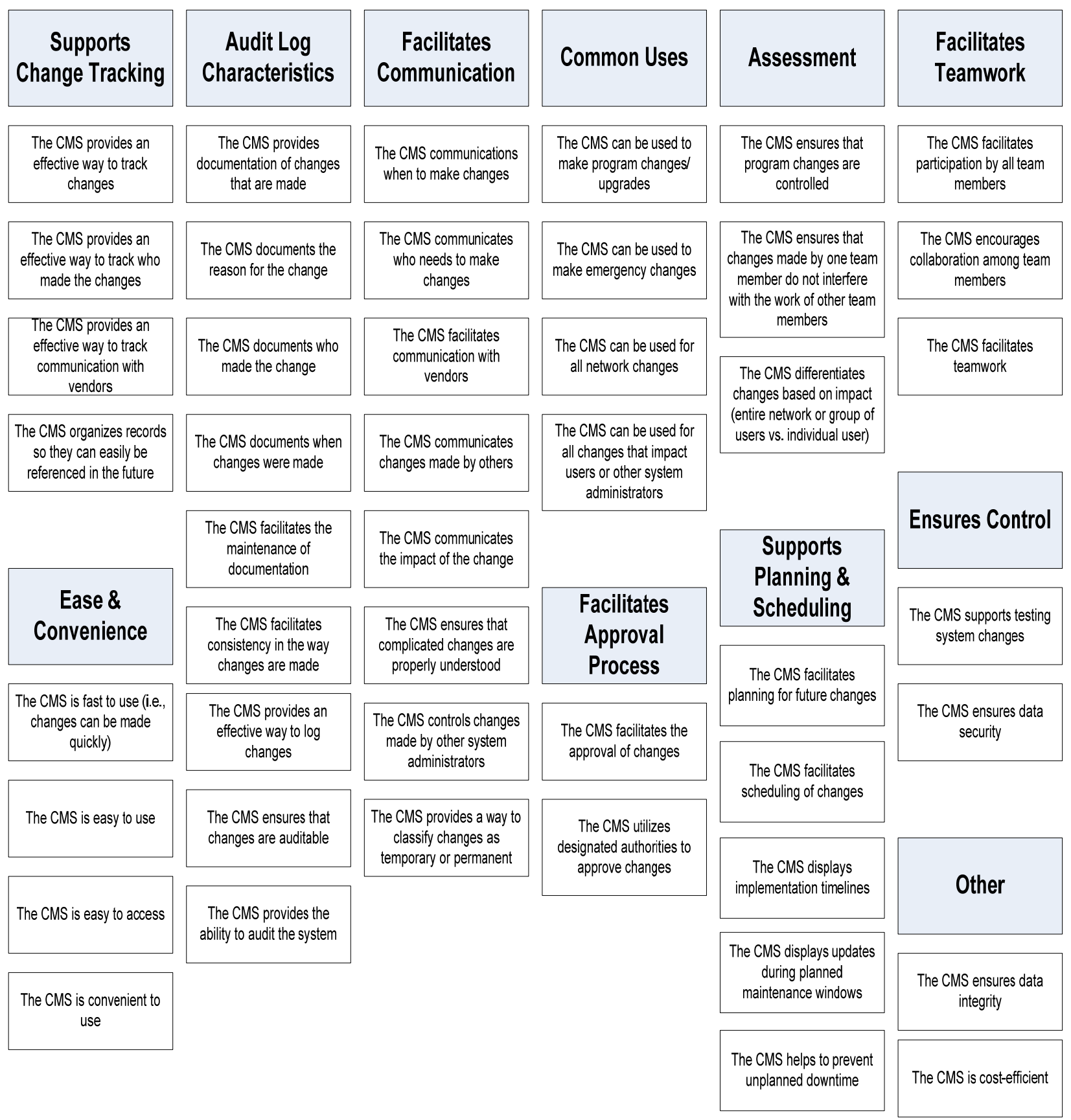

Figure 3. Summary of users' needs obtained from interviews

According to Ulrich and Eppinger (2004), "While the process of identifying customer needs can be usefully structured, it is not an exact science. The survey responses for each need statement can be characterized in a variety of ways: by the mean, by the standard deviation, or by the number of responses in each category. The responses can then be used to assign an importance weighting to the need statements." In terms of the CTQs for this project, the design team selected to focus on the 10 needs that received the largest percentage of responses in the "highly desirable" and "critical" categories (i.e., ratings 4 and 5), as shown in Figure 5. Table 3 shows the importance weighting assigned to these 10 needs based on median survey responses. Focusing on these needs in the subsequent phases of this project will help the design team ensure that the final design fulfills the needs of the work environment for which it is being created. 


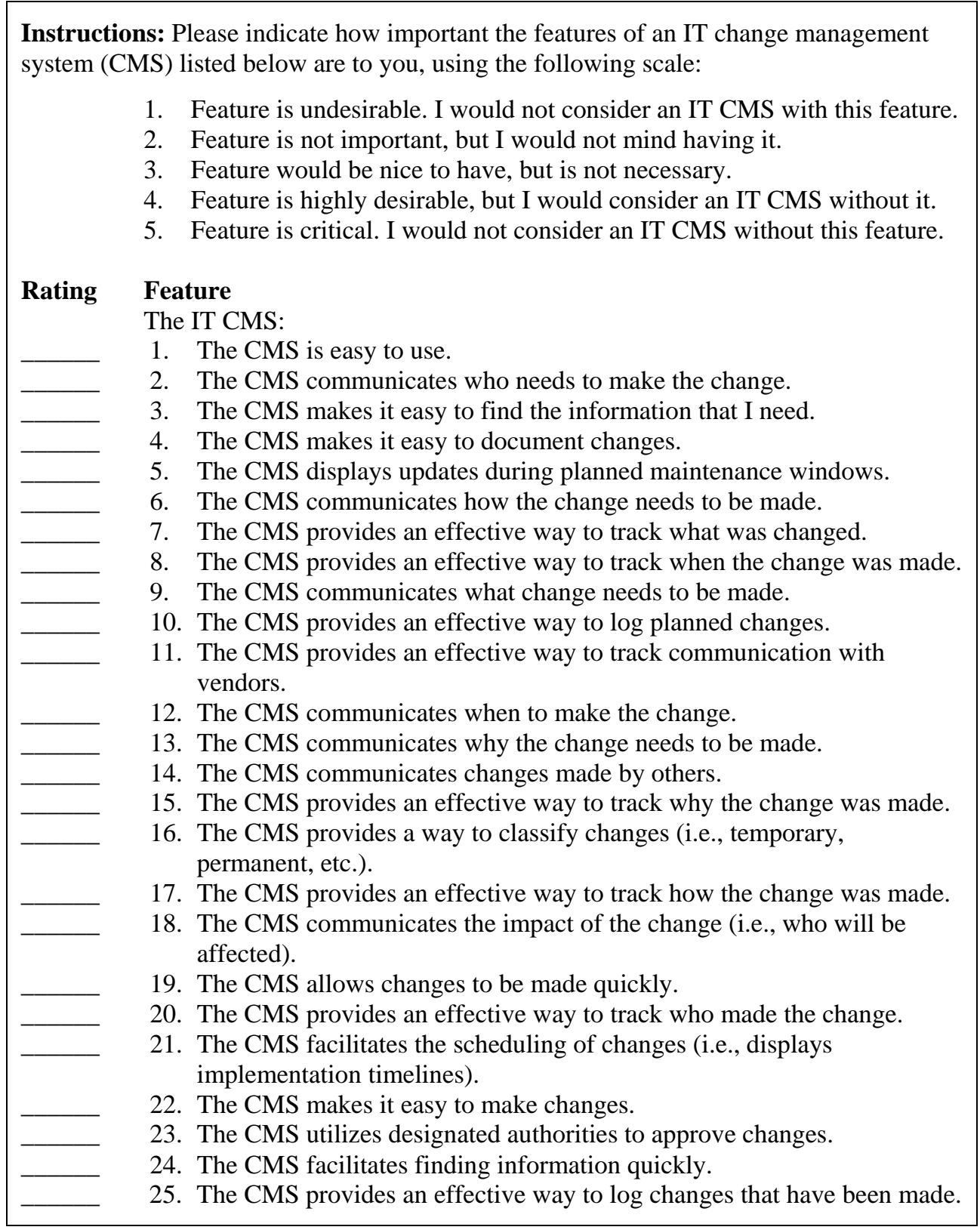

Figure 4. User needs survey

3.3 Analyze: In the analyze phase, brainstorming and benchmarking were used to generate high-level, potential design ideas. This work involved a total of 11 interviews, as shown in Table 4, to collect ideas from internal as well as external informants in the IT field and beyond. The people interviewed included the IT department manager, internal IT staff, and other firm employees, as well as IT managers from other firms and users of change management systems from other industries, including project managers and firefighters. In these interviews, participants were asked to describe 1) the methods they use to track and communicate changes/updates, 2) how these methods work, and 3) the advantages and disadvantages associated with these methods. The information obtained from these interviews was categorized in an affinity diagram, which is depicted in Figure 6 . This diagram was then presented to the IT staff as part of a focus group in which this information was discussed, design ideas were further refined, and the team reached agreement about specific design ideas that should be incorporated into the detailed design of the new process for managing IT system changes. These elements are highlighted by bold boxes in Figure 6. 


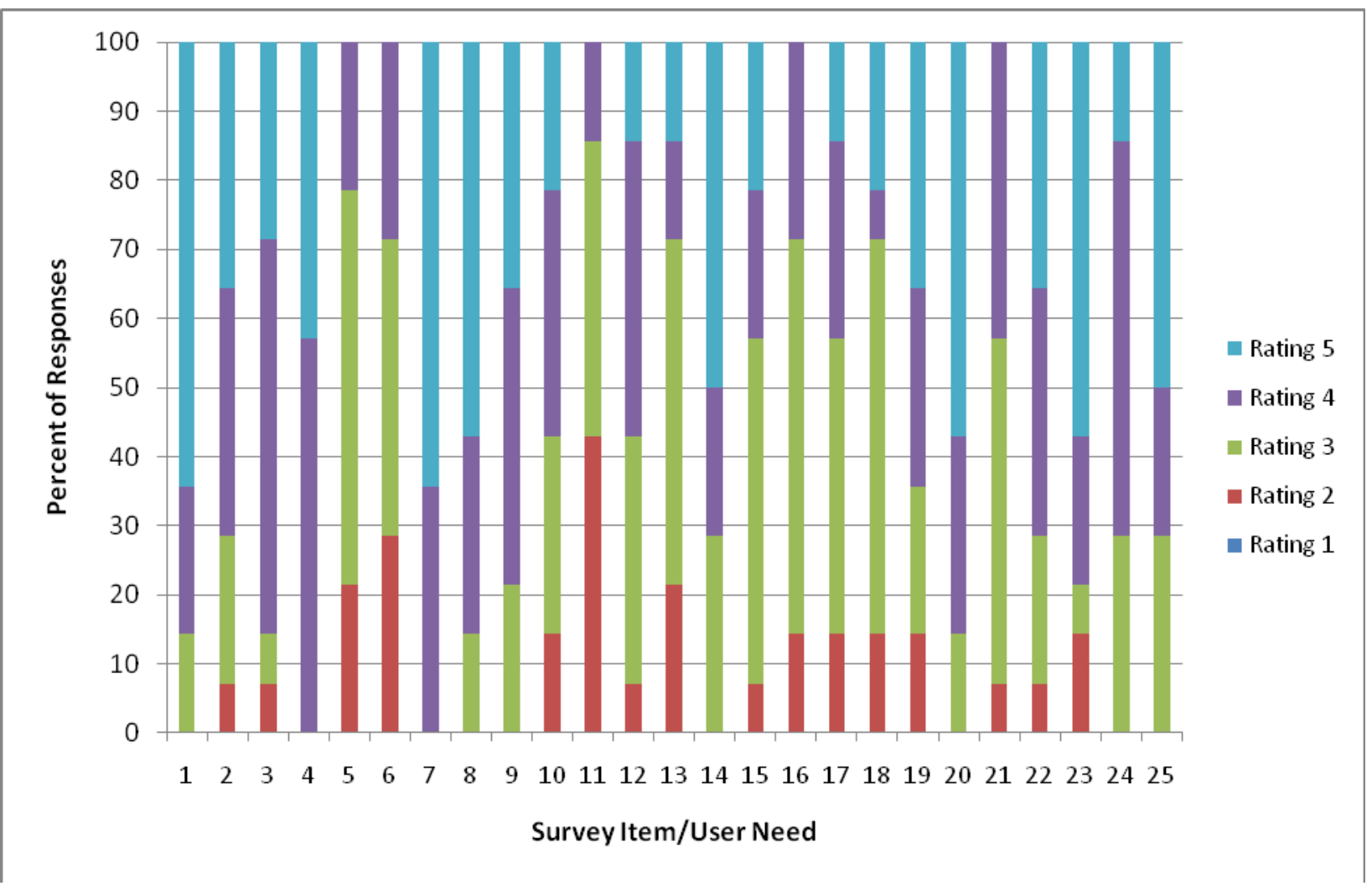

Figure 5. Results of users' needs survey

Table 3. Importance of user's needs based on median importance ratings

\begin{tabular}{|c|c|l|c|}
\hline No. & $\begin{array}{c}\text { Survey } \\
\text { Item No. }\end{array}$ & \multicolumn{1}{|c|}{ Users' Needs (CTQs) } & Importance \\
\hline 1 & 1 & The CMS is easy to use. & 5 \\
\hline 2 & 3 & The CMS makes it easy to find the information that I need. & 4 \\
\hline 3 & 4 & The CMS makes it easy to document changes. & 4 \\
\hline 4 & 7 & The CMS provides an effective way to track what was changed. & 5 \\
\hline 5 & 8 & $\begin{array}{l}\text { The CMS provides an effective way to track when the change was } \\
\text { made. }\end{array}$ & 5 \\
\hline 6 & 14 & The CMS communicates changes made by others. & 4.5 \\
\hline 7 & 20 & The CMS provides an effective way to track who made the change. & 5 \\
\hline 8 & 23 & The CMS utilizes designated authorities to approve changes. & 5 \\
\hline 9 & 24 & The CMS facilitates finding information quickly. & 4 \\
\hline 10 & 25 & $\begin{array}{l}\text { The CMS provides an effective way to log changes that have been } \\
\text { made. }\end{array}$ & 4.5 \\
\hline
\end{tabular}

Table 4. Brainstorming and benchmarking interview participants

\begin{tabular}{|c|c|c|c|}
\hline \multirow{2}{*}{ Field } & \multicolumn{2}{|c|}{ Informant } & \multirow{2}{*}{ Total } \\
\cline { 2 - 3 } & Internal & External & \\
\hline Same (IT) & 3 & 4 & 7 \\
\hline $\begin{array}{c}\text { Different } \\
\text { (Non-IT) }\end{array}$ & 2 & 2 & 4 \\
\hline Total & 5 & 6 & 11 \\
\hline
\end{tabular}




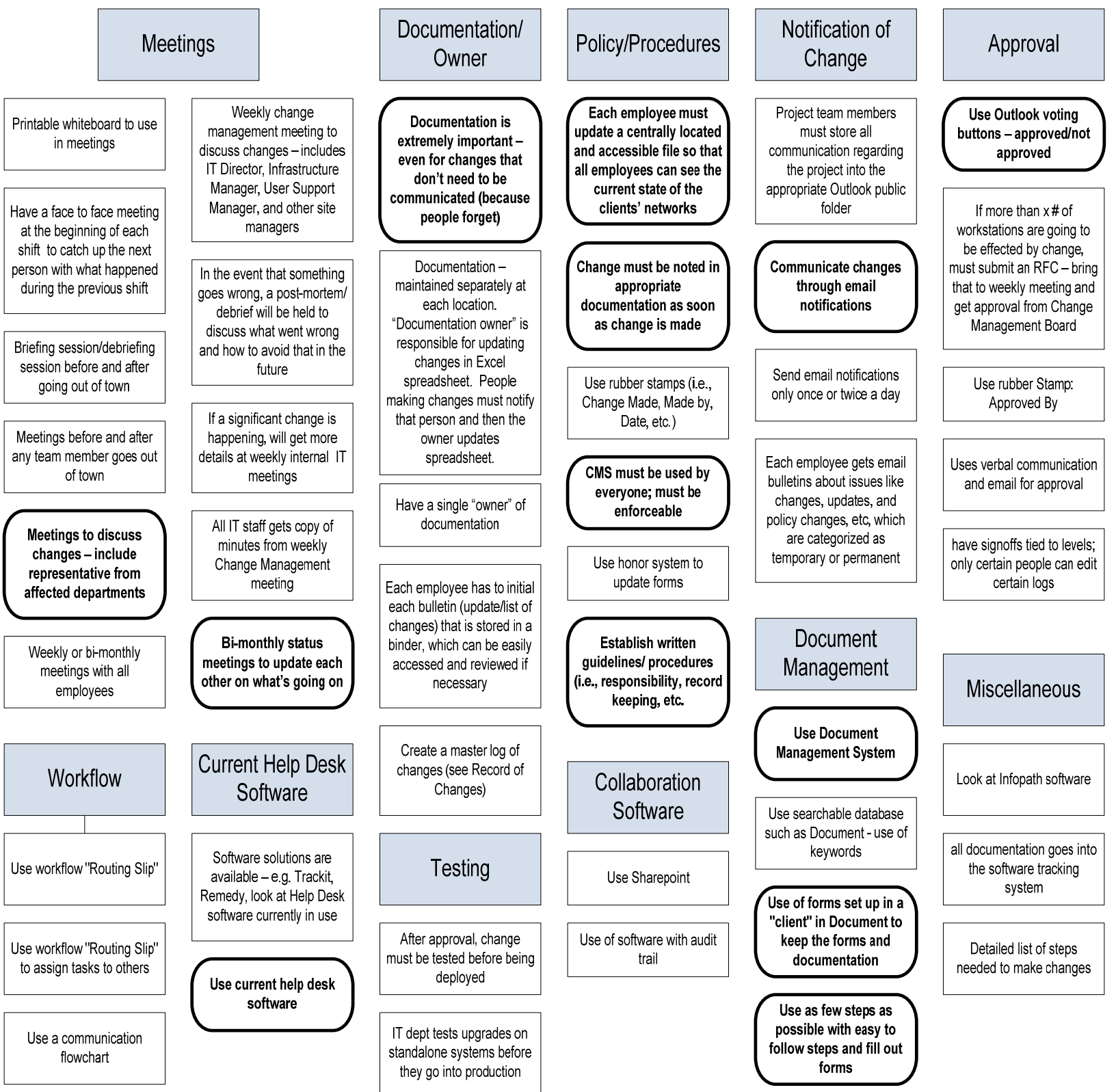

Figure 6. Summary of preliminary design ideas obtained from benchmarking

3.4 Design: The design phase of this project focused on developing a detailed design for the new IT change management system. The design team first developed a general structure, illustrated in Figure 7, for the critical elements to be addressed by the new process for managing IT system changes. This framework included 1) developing policies and procedures, 2) addressing communication requirements, 3) addressing documentation requirements, and 4) utilizing software to facilitate operations. The design team felt that the policies and procedures were important because they would dictate the terms of use for the new system. In addition, they believed the other elements included in this framework were essential for guiding the daily operations of the new system. 


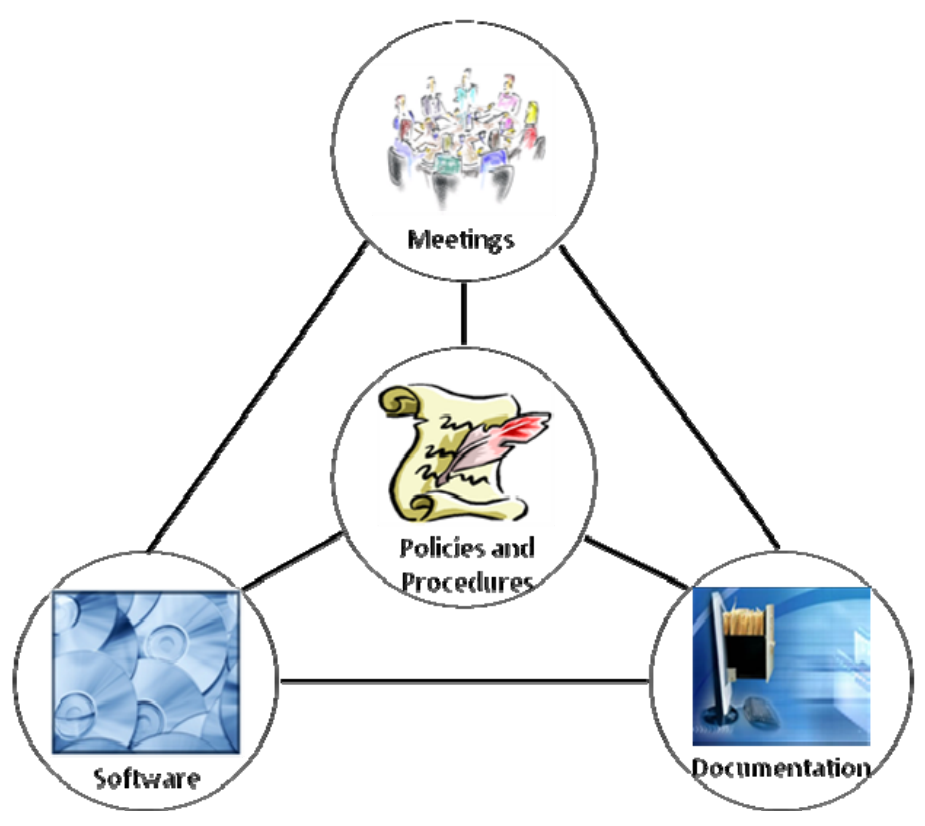

Figure 7. The structure of the new IT change management system

Next, the design team focused on identifying the specific requirements or CTPs that the new process needed to address. These are given in the needs-metrics matrix shown in Figure 8. Much like what is done in Quality Function Deployment within the House of Quality (Hauser \& Clausing, 1988), the dots in Figure 8 indicate which needs are addressed by each design requirement. Special attention was given to ensure that each CTQ is addressed by at least one CTP. In addition, the importance, units, and baseline measurement for each metric is specified in Table 5. The importance of the CTPs was determined based on the importance of the needs they address. The units selected for each metric reflect the appropriate measurement method for each design requirement. The baseline measurements were also documented to establish a record of the current state of the process before the new system was implemented. Metrics such as "time to document a change" and "time to find information" do not have baseline measurements because, at the time, there was no formal system to document this information within the IT department. Subjective metrics, like "system ease-of-use" and "system effectiveness," were measured through an additional user survey (see Figure 9) using a 5-point scale, where a rating of 1 represented "falls well short of expectations" and 5 represented "greatly exceeds expectations." This survey was administered to all IT department staff, and the values recorded for the baseline measurement for the remaining metrics were the median rating obtained from the survey and documentation of other aspects of the current system.

Finally, a concept selection matrix was used to select the "best" design concept. As shown in Table 6, the design concepts developed through the analyze phase of this project (i.e., software packages, etc.) are listed across the top of the matrix, and the criteria by which each concept was judged (i.e., design requirements/CTPs) are listed down the left-most column. One additional selection criterion, "easy to implement," was included to ensure that solutions requiring significant behavioral changes or additional expenses were properly accounted for in this analysis. In this evaluation, each design concept was rated by the design team using a 3-point scale, where a rating of 1 represented "will not meet need," 2 represented "will fulfill need," and 3 represented "will exceed expectations for need."

The design concept with the highest score in the selection matrix was the current Help Desk software; hence, the design team decided to use this software package to implement the new IT change management system. Even though the Help Desk software had been used for some time in the IT department, it is important to note that the change management functions within this software package had not previously been used. As part of the detailed design, the team also decided to 1) continue their bi-weekly meetings to communicate and discuss changes, 2) maintain network and application documentation in the firm's Document Management software, and 3) establish policies and procedures for the new IT change management process, which included:

1. The IT change management system shall be used for all changes that affect production systems.

2. All IT staff shall:

a. Use the change management system, and

b. Keep documentation of changes up-to-date.

3. Policy compliance audits shall be conducted periodically by the IT manager as well as IT staff (i.e., peer reviews).

Once created, the detailed design was tested through a two week pilot study in the IT department. At the conclusion of this pilot test, additional interviews/focus groups were conducted to ensure the design fulfilled the needs of the IT department. Slight 
adjustments were made based on the results of the pilot study in order to create the final design of the new IT change management system.

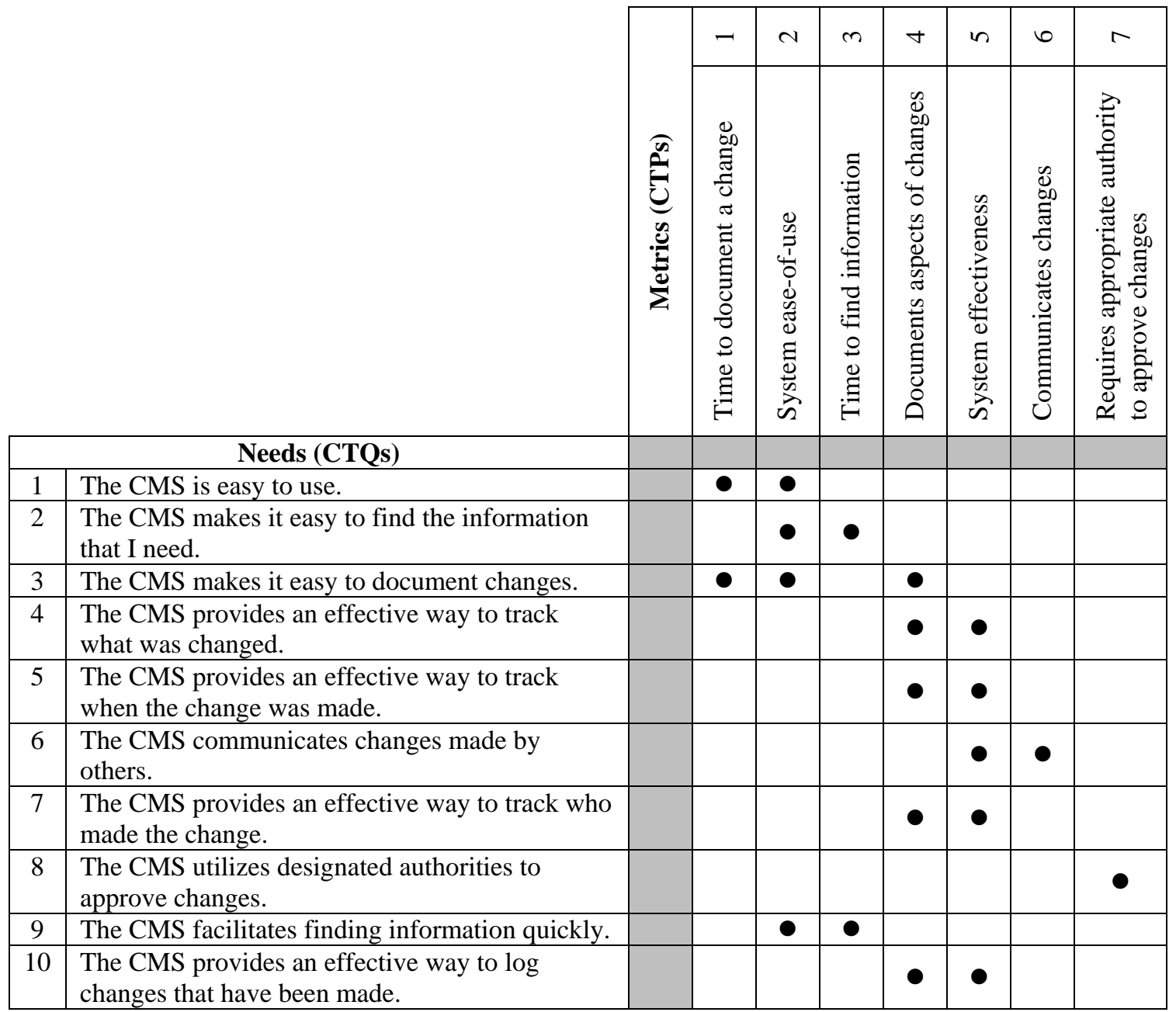

Figure 8. Needs-metrics matrix

Table 5. Baseline measurements for design requirements

\begin{tabular}{|c|c|l|c|c|c|}
\hline $\begin{array}{c}\text { Metric } \\
\text { No. }\end{array}$ & $\begin{array}{c}\text { Need } \\
\text { Nos. }\end{array}$ & \multicolumn{1}{|c|}{ Metric } & Importance & \multicolumn{1}{|c|}{ Units } & $\begin{array}{c}\text { Baseline } \\
\text { Measurement }\end{array}$ \\
\hline 1 & 1,3 & Time to document a change & 4.5 & Minutes (min.) & -- \\
\hline 2 & $1-3,9$ & System ease-of-use & 4 & 5 pt. scale & 2 \\
\hline 3 & 2,9 & Time to find information & 4 & Seconds (s) & -- \\
\hline 4 & $3-5,7,10$ & Documents aspects of changes & 5 & Binary & No \\
\hline 5 & $4-7,10$ & System effectiveness & 5 & 5 pt. scale & 1 \\
\hline 6 & 6 & Communicates changes & 4.5 & Binary & No \\
\hline 7 & 8 & $\begin{array}{l}\text { Requires appropriate authority } \\
\text { to approve changes }\end{array}$ & 5 & Binary & No \\
\hline
\end{tabular}




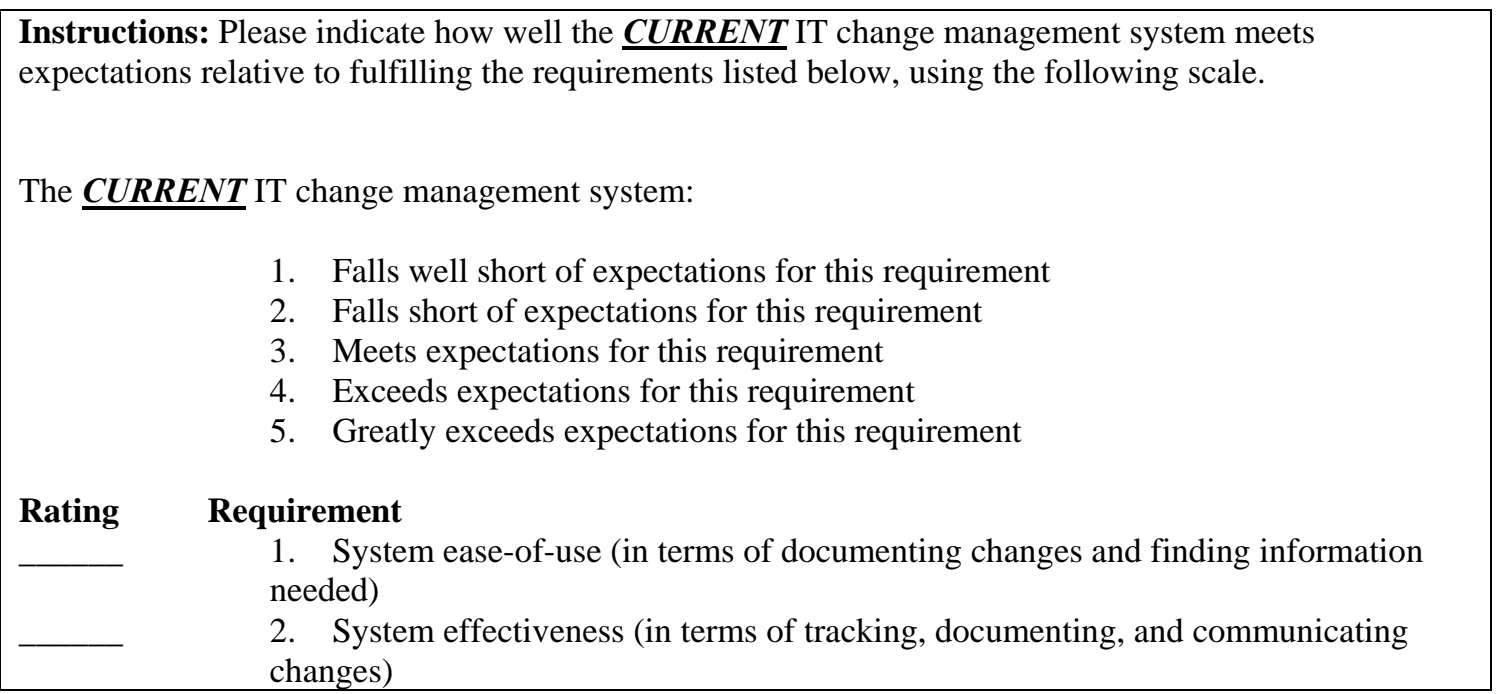

Figure 9. User expectations survey (current system)

3.5 Verify: Once the final design of new process for managing IT system changes had been in use for approximately three months, several measurements were taken to evaluate whether the new system fulfilled the needs for which it was designed. As shown in Table 7, various aspects built into the new system were documented and compared against baseline measurements to acknowledge the degree of improvement achieved by the new system. Specifically, the "time to document a change" and "time to find information” was determined through several observations of IT department staff using the new system. On average, it now takes 1.65 minutes to document a change and just 9 seconds to find the information they need within the new IT change management system. In terms of "system ease-of-use” and "system effectiveness," again these aspects were measured through a user survey, similar to that shown in Figure 9, however it asked IT department staff to indicate how well the "new" system met expectations relative to fulfilling the requirements of ease-of-use and effectiveness - both of which were rated higher for the new system compared to the previous system.

For comparison purposes, survey responses regarding "system ease-of-use” for the previous system versus the new system are shown in Figure 10. Chi-square analysis was used to examine proportional changes in ease-of-use ratings between these systems. As shown in Table 8, changes in the IT department staffs' ratings of ease-of-use for the previous system versus the new system were significant $(p$-value $=0.0183)$. Figure 11 illustrates survey responses for "system effectiveness" for the two systems. Again, chi-square analysis (see Table 9 ) indicates that changes in IT department staffs' ratings of system effectiveness were significant ( $p$ value $=0.0460$ ). In other words, there is some evidence to suggest that the new system had a positive impact on improving system ease-of-use and effectiveness.

Table 6. Concept selection matrix

\begin{tabular}{|c|c|c|c|c|c|c|c|c|c|c|}
\hline \multirow[b]{2}{*}{$\begin{array}{l}\text { Selection } \\
\text { Criteria }\end{array}$} & \multicolumn{10}{|c|}{$\begin{array}{c}\text { Design Concept } \\
\text { (Scale: } 1 \text { = Will not met need; } 2=\text { Will fulfill need; } 3=\text { Will exceed expectations for need) }\end{array}$} \\
\hline & $\begin{array}{l}\text { Workflow } \\
\text { Software }\end{array}$ & Sharepoint & $\begin{array}{c}\text { Current } \\
\text { Help } \\
\text { Desk } \\
\text { Software } \\
\end{array}$ & $\begin{array}{c}\text { New } \\
\text { Help } \\
\text { Desk } \\
\text { Software } \\
\end{array}$ & $\begin{array}{l}\text { Infopath } \\
\text { Software }\end{array}$ & Outlook & $\begin{array}{l}\text { Adobe } \\
\text { Forms }\end{array}$ & Checklists & $\begin{array}{l}\text { Rubber } \\
\text { Stamps }\end{array}$ & Meetings \\
\hline $\begin{array}{ll}\text { 1. } & \text { Time to } \\
\text { document } \\
\text { changes }\end{array}$ & 1 & 1 & 3 & 2 & 1 & 2 & 2 & 2 & 1 & 3 \\
\hline $\begin{array}{ll}2 . & \text { System } \\
\text { ease-of-use } \\
\text { (in terms of } \\
\text { documentin } \\
\text { g changes } \\
\text { and finding } \\
\text { information } \\
\text { needed) }\end{array}$ & 3 & 1 & 3 & 2 & 1 & 1 & 3 & 3 & 3 & 3 \\
\hline
\end{tabular}


Table 6 (cont'd). Concept selection matrix

\begin{tabular}{|c|c|c|c|c|c|c|c|c|c|c|}
\hline \multirow[b]{2}{*}{$\begin{array}{l}\text { Selection } \\
\text { Criteria }\end{array}$} & \multicolumn{10}{|c|}{$\begin{array}{c}\text { Design Concept } \\
\text { (Scale: } 1 \text { = Will not met need; } 2 \text { = Will fulfill need; } 3=\text { Will exceed expectations for need) }\end{array}$} \\
\hline & $\begin{array}{l}\text { Workflow } \\
\text { Software }\end{array}$ & Sharepoint & $\begin{array}{c}\text { Current } \\
\text { Help } \\
\text { Desk } \\
\text { Software }\end{array}$ & $\begin{array}{c}\text { New } \\
\text { Help } \\
\text { Desk } \\
\text { Software }\end{array}$ & $\begin{array}{l}\text { Infopath } \\
\text { Software }\end{array}$ & Outlook & $\begin{array}{l}\text { Adobe } \\
\text { Forms }\end{array}$ & Checklists & $\begin{array}{l}\text { Rubber } \\
\text { Stamps }\end{array}$ & Meetings \\
\hline $\begin{array}{ll}\text { 3. } & \text { Time to } \\
\text { document } \\
\text { changes }\end{array}$ & 1 & 1 & 3 & 2 & 1 & 2 & 2 & 2 & 1 & 3 \\
\hline $\begin{array}{ll}\text { 4. } & \text { System } \\
\text { ease-of-use } \\
\text { (in terms of } \\
\text { documentin } \\
\text { g changes } \\
\text { and finding } \\
\text { information } \\
\text { needed) }\end{array}$ & 3 & 1 & 3 & 2 & 1 & 1 & 3 & 3 & 3 & 3 \\
\hline $\begin{array}{ll}\text { 5. Time to } \\
\text { find } \\
\text { information }\end{array}$ & 2 & 2 & 3 & 2 & 1 & 2 & 1 & 1 & 1 & 1 \\
\hline $\begin{array}{l}\text { 6. } \begin{array}{l}\text { Aspects of } \\
\text { changes }\end{array} \\
\text { can be } \\
\text { documente } \\
\text { d (i.e., } \\
\text { what, } \\
\text { when, who, } \\
\text { etc.) }\end{array}$ & 2 & 3 & 3 & 3 & 1 & 1 & 2 & 3 & 1 & 1 \\
\hline $\begin{array}{l}\text { 7. } \begin{array}{l}\text { System } \\
\text { effectivene }\end{array} \\
\text { ss (in terms } \\
\text { of tracking, } \\
\text { documentin } \\
\text { g, and } \\
\text { communica } \\
\text { ting } \\
\text { changes) } \\
\end{array}$ & 2 & 3 & 3 & 3 & 3 & 1 & 1 & 1 & 1 & 1 \\
\hline $\begin{array}{l}\text { 8. } \begin{array}{l}\text { Changes } \\
\text { can be } \\
\text { communica } \\
\text { ted }\end{array} \\
\end{array}$ & 3 & 2 & 3 & 2 & 3 & 3 & 3 & 2 & 2 & 3 \\
\hline $\begin{array}{ll}\text { 9. } & \text { Approval } \\
& \text { authority } \\
\text { options }\end{array}$ & 2 & 2 & 3 & 3 & 2 & 1 & 2 & 2 & 1 & 3 \\
\hline $\begin{array}{l}\text { 10. Ease of } \\
\text { implementa } \\
\text { tion }\end{array}$ & 2 & 1 & 3 & 1 & 1 & 3 & 2 & 3 & 3 & 3 \\
\hline Total & 17 & 15 & 24 & 18 & 13 & 14 & 16 & 17 & 13 & 18 \\
\hline
\end{tabular}


Table 7. Baseline and verification measurements for design requirements

\begin{tabular}{|c|c|l|c|c|c|c|}
\hline $\begin{array}{c}\text { Metric } \\
\text { No. }\end{array}$ & Need Nos. & \multicolumn{1}{|c|}{ Metric } & Importance & \multicolumn{1}{|c|}{ Units } & $\begin{array}{c}\text { Previous } \\
\text { System }\end{array}$ & $\begin{array}{c}\text { New } \\
\text { System }\end{array}$ \\
\hline 1 & 1,3 & Time to document a change & 4.5 & Minutes (min.) & -- & 1.65 min. \\
\hline 2 & $1-3,9$ & System ease-of-use & 4 & 5 pt. scale & 2 & 4.5 \\
\hline 3 & 2,9 & Time to find information & 4 & Seconds (s) & -- & $9 \mathrm{~s}$ \\
\hline 4 & $3-5,7,10$ & Documents aspects of changes & 5 & Binary & No & Yes \\
\hline 5 & $4-7,10$ & System effectiveness & 5 & 5 pt. scale & 1 & 4 \\
\hline 6 & 6 & Communicates changes & 4.5 & Binary & No & Yes \\
\hline 7 & 8 & $\begin{array}{l}\text { Requires appropriate authority } \\
\text { to approve changes }\end{array}$ & 5 & Binary & No & Yes \\
\hline
\end{tabular}

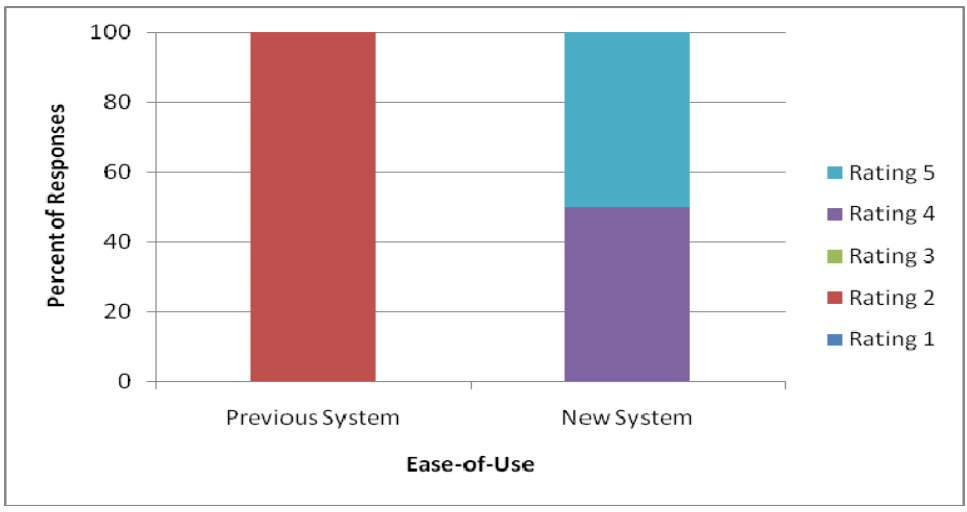

Figure 10. Survey responses for system ease-of-use

Table 8. Comparison of system ease-of-use for the new versus the previous system

\begin{tabular}{|c|c|c|c|c|c|c|c|c|}
\hline \multirow[b]{2}{*}{ Ease-of-Use } & \multirow[b]{2}{*}{ Counts } & \multicolumn{5}{|c|}{ Rating Categories* $(n=4)$} & \multirow[b]{2}{*}{$\chi^{2}$-value } & \multirow[b]{2}{*}{$p$-value } \\
\hline & & 1 & 2 & 3 & 4 & 5 & & \\
\hline \multirow{2}{*}{ Previous System } & Count & 0 & 4 & 0 & 0 & 0 & \multirow{4}{*}{8.00} & \multirow{4}{*}{0.0183} \\
\hline & Expected Count & 0 & 2 & 0 & 1 & 1 & & \\
\hline \multirow{2}{*}{ New System } & Count & 0 & 0 & 0 & 2 & 2 & & \\
\hline & Expected Count & 0 & 2 & 0 & 1 & 1 & & \\
\hline
\end{tabular}

To maintain the improvements achieved through this project, the design team developed a control plan for the IT department/company that consists of documentation, training, and system monitoring. The instructions for using the new IT change management system were documented in standard operating procedures. The new policies for the change management process described previously were incorporated into the company's Information Technology Infrastructure Protection and Security Policy. All IT department staff, along with other employees involved in the change approval process, were trained on these new policies and procedures. As new employees are hired, this information will be covered as part of their new-hire training program. In addition, the use of the new system will be monitored by the IT manager through regular audits to ensure the system is being used in accordance with the new policies and procedures. 


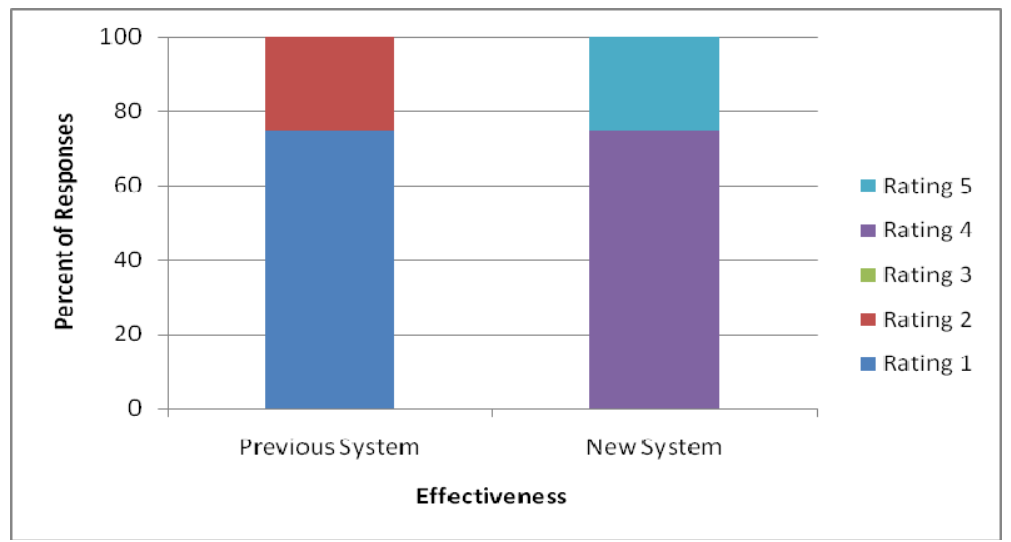

Figure 11. Survey responses for system effectiveness

Table 9. Comparison of system effectiveness for the new versus the previous system

\begin{tabular}{|c|c|c|c|c|c|c|c|c|}
\hline \multirow{2}{*}{ Effectiveness } & \multirow{2}{*}{ Counts } & \multicolumn{5}{|c|}{ Rating Categories* $(n=4)$} & \multirow{2}{*}{$\chi^{2}$-value } & \multirow{2}{*}{$p$-value } \\
\hline & & 1 & 2 & 3 & 4 & 5 & & \\
\hline \multirow{2}{*}{ Previous System } & Count & 3 & 1 & 0 & 0 & 0 & \multirow{4}{*}{8.00} & \multirow{4}{*}{0.0460} \\
\hline & Expected Count & 1.5 & 0.5 & 0 & 1.5 & 0.5 & & \\
\hline \multirow{2}{*}{ New System } & Count & 0 & 0 & 0 & 3 & 1 & & \\
\hline & Expected Count & 1.5 & 0.5 & 0 & 1.5 & 0.5 & & \\
\hline
\end{tabular}

\section{Conclusions}

The work completed in this project illustrates the effective use of the DFSS methodology to create an IT change management system in a mid-sized accounting firm. By using the DMADV process and associated tools, users' needs were identified and a new process was established that effectively fulfilled the needs of the work environment for which it was designed. The use of this structured design approach achieved several positive outcomes for the organization overall and for the IT department, specifically. Throughout the DFSS process, all members of the IT department worked together closely to improve the communication of system changes. Since the IT staff are the users of the new system and they helped to design it (i.e., their needs and ideas were considered and integrated into the final design), little to no resistance to using the new system was encountered during implementation. Hence, the new change management system has become an integral part of the daily work processes of the IT department. Several months after implementation, the new change management system continues to be successfully used by the entire IT department, including their external consultant. The driving force for creating this new system was to stabilize the IT environment for the company. By enhancing communication between all the members of the IT department, providing an approval process for network changes, and maintaining documentation of what changes were made when and by whom, the new change management system has enabled the IT department to reduce overall network downtime and accelerate resolution time of network issues. The successful implementation of a complete design solution has led to the effective management of changes within the IT department. This new process specifically helped to improve the communication of changes, awareness about changes, and the timely identification of prior changes that may be related to current problems faced by the IT department. As a result, the new system has had a positive impact on reducing unplanned downtime and IT staff frustration, as well as improving productivity and customer satisfaction for the organization as a whole. Based on this success of this project, the IT department is now looking at additional ways to further improve the service they provide to their customers.

\section{References}

Allison, D.H. and P.B. DeBlois, Top 10 IT Issues 2008. Educause Review, 2008. Vol. 43, No. 3, pp. 37-61.

Banuelas, R. and J. Antony, Going from six sigma to design for six sigma: an exploratory study using analytic hierarchy process

The TQM Magazine, 2003. Vol. 15, No. 5: p. 334-344.

Banuelas, R. and J. Antony, Six sigma or design for six sigma? The TQM Magazine, 2004. Vol. 16, No. 4, pp. 250-263.

Berardinelli, C., et al., DFSS Lights the Way. Six Sigma, Forum Magazine, 2009. Vol. 8, No. 3, pp. 23-29.

Bitner, M.J., A. Ostrom, and F. Morgan, Service blueprinting: A practical technique for service innovation. California

Management Review, 2008. Vol. 50, No. 3, pp. 66-94.

Brittain, K., 2008 Data Center Polling Shows Little Change Control for Emerging Technologies, in Gartner Research Report. 2009, Gartner, Inc.: Stamford, CT.

Brittain, K., Conference Polling Underscores Slow Gains for IT Change Management, in Gartner Research Report. 2008, Gartner, 
Inc.: Stamford, CT.

Brittain, K., The ITCM Market Presents a Confusing Vendor Landscape, in Gartner Research Report. 2007, Gartner, Inc.: Stamford, CT.

Brue, G. and R.G. Launsby, Design for Six Sigma. 2003, New York: McGraw-Hill.

Chowdhury, S., Design for Six Sigma: The Revolutionary Process for Achieving Extraordinary Profits. 2002, Chicago: Dearborn Trade Publishing.

Chowdhury, S., The Power of Design for Six Sigma. 2003, Chicago: Dearborn Trade.

Creveling, C.M., J. Slutsky, and D. Antis, Design for Six Sigma in technology and product development. 2003, Upper Saddle River, NJ: Prentice Hall.

El-Haik, B. and D.M. Roy, Service design for six sigma: a roadmap for excellence. 2005, Hoboken, NJ: John Wiley.

Ferweda, N., Largest Houston-Area Public Accounting Firms. Houston Business Journal, 2009: p. Week of May 28-June3.

Gitlow, H.S., D.M. Levine, and E.A. Popovich, Design for six sigma for green belts and champions: applications for service operations--foundations, tools, DMADV, cases, and certification 2006, Upper Saddle River, NJ: Pearson Prentice Hall.

Harry, M. and R. Schroeder, Six Sigma: The Breakthrough Management Strategy Revolutionizing the World's Top Corporations. 2000, New York: Doubleday.

Hasenkamp, T., Engineering Design for Six Sigma-a systematic approach. Quality and Reliability Engineering International, 2010. Vol. 26, No. 4: p. 317-324.

Hauser, J.R. and D. Clausing, The house of quality. Harvard Business Review, 1988. Vol. 66, No. 3: p. 63-73.

Heskett, J.L., et al., Putting the Service Profit Chain to Work. Harvard Business Review, 2008. Vol. 86, No. 7/8: p.118-129.

Kulahci, M., D. Holcomb, and M. Xie, Design for Six Sigma special issues - editorial. Quality and Reliability Engineering International, 2010. Vol. 26, No. 4: p. 315.

Marwil, J.J. and J.J. Burgdoerfer (2006) Compliance Programs for Private Companies. The Corporate Compliance \& Regulatory Newsletter.

Microsoft (2010) Increased Risk of IT Failure. Microsoft TechNet.

Montgomery, D.C. and W.H. Woodall, An overview of six sigma. International Statistical Review, 2008. Vol. 76, No. 3: p. 329346.

Peregrine-Systems (2005) The Peregrine Evolution Model for Service Management.

Pheonix, H. (2010) Hidden threats to enterprise: Will your business continuity go according to plan? Financial Services

Technology.

Schroeder, R.G., et al., Six Sigma: Definition and underlying theory. Journal of Operations Management, 2008. Vol. 26, No. 4: p. 536-554.

Shahin, A., Design for Six Sigma (DFSS): lessons learned from world-class companies. International Journal of Six Sigma and Competitive Advantage, 2008. Vol. 4, No. 1: p. 48-59.

Stickel, E. (2005) Change Control vs. Change Management: Moving Beyond IT. ITSMWatch - Insight on IT Service Management.

Treichler, D., et al., Design for six sigma: 15 lessons learned. Quality Progress, 2002. Vol. 35, No. 1: p. 33-42.

Ulrich, K.T. and S.D. Eppinger, Product Design and Development. 3rd ed. 2004, New York: McGraw Hill/Irwin.

Verizon-Business (2009) 2009 Data Breach Investigations Report.

Yang, K. and B. El-Haik, Design for Six Sigma: A Roadmap for Product Development. 2003, New York: McGraw-Hill.

Yang, Y., Design for Six SIGMA for Service. 2005, New York: McGraw-Hill.

\section{Biographical notes}

Patricia Long received her M.S. in Technology Project Management from the University of Houston. She has over 13 years experience in the Information Technology field, and she is a PMI certified Project Management Professional and a Six Sigma Green Belt. She has recently presented her research on quality improvement in IT at the Industrial Engineering Research Conference and the Project Management Institute Houston Conference and Expo, as well as at the Project Management Institute Education and Research Conference.

Jamison V. Kovach is an Assistant Professor in the Department of Information and Logistics Technology at the University of Houston. She received her Ph.D. in Industrial Engineering from Clemson University. Her industrial experience includes several years as a product and process improvement engineer in the U.S. textile industry. Her responsibilities included working within both ISO 9000 and QS 9000 quality management systems and improving the shade quality of apparel and automotive dyed fabrics. Currently, her research interests include robust design, experimental design, and the application of quality improvement and management methods for organizational problem solving. She is certified in Six Sigma Black Belt training and is the Director of the Six Sigma program at the University of Houston. Through this program, she instructs students and industrial clients on the use of Six Sigma and other quality improvement initiatives within their organizations. Her research has been published in Engineering Optimization, Quality Engineering, and International Journal of Quality and Reliability Management journals, and she is a member of ASQ, IIE, DSI, PMI, and POMS. She is the recipient of the ASQ 2010 Feigenbaum Medal.

David Ding is an Assistant Professor at the Information and Logistics Technology Department at the University of Houston. He received his Ph.D. in Operations Management from David Eccles School of Business, University of Utah. His research examines service design and information technology in financial service and health care industries. He has published in leading service and business research journals such as Journal of Service Research, Journal of Business Research, and Journal of Service Management.

Received December 2010

Accepted February 2011

Final acceptance in revised form May 2011 